\title{
Elizabethan Parliamentary Oratory
}

Peter Mack

P

arliament was the highest public arena of debate in Elizabethan England. In Parliament gentlemen from the shires could hear the greatest officials of state explain their policies and legislative projects, sometimes in the face of critical arguments and counterproposals. Persuasion, explanation, and argument are the province of rhetoric, the main component of Tudor grammar school education. Parliamentary oratory thus enables us to examine the impact of humanist rhetorical training in practice. At the same time, rhetorical theory can help us understand the effect of individual speeches as well as the broader import of parliamentary discourse.

Much of the Tudor grammar school curriculum was given over to studies and composition exercises connected with rhetoric. Boys learned to write commonplaces, themes, and theses. They were trained to analyze the rhetorical impact of texts, to collect pithy sayings for reuse in their own compositions, to amplify and abbreviate, to recognize and use tropes and figures of speech, and to adjust the subject matter and tone of letters to suit their correspondents. ${ }^{1}$ Those who went on to university, as a large proportion of MPs did, studied

Sections of this essay derive from papers given at the eleventh biennial congress of the International Society for the History of Rhetoric, held in Saskatoon in July 1997; at the University of Leeds in January 1998; and at the University of Tennessee in February 1999. I am grateful to Linda Bensel-Meyers, Lawrence D. Green, Steve Hindle, Sophie Holroyd, and Sue Wiseman for encouragement, suggestions, and criticisms of earlier drafts.

1. The most comprehensive account of the Tudor grammar school syllabus is T. W. Baldwin, Shakspere's Small Latine and Lesse Greeke, 2 vols. (Urbana, Ill., 1944), but some of Baldwin's conclusions need to be treated with caution and checked against the abundant primary evidence he collects. The studies mentioned above are outlined in standard grammar school textbooks such as Aphthonius's Progymnasmata and Erasmus's De copia and De conscribendis epistolis and in two contemporary teachers' guides, William Kempe, The Education of Children in Learning (London, 1588); and John Brinsley, Ludus Literarius (London, 1612). These matters are discussed in more detail in my forthcoming book, Elizabethan Rhetoric (Cambridge, 2002). 
Cicero's speeches and Aristotle's logic, composed declamations, and took part in disputations. $^{2}$

Many of the formal features of parliamentary speeches can be connected with rhetorical training. Long speeches draw on rhetorical doctrines (for example, about the organization of a speech and the contents of an introduction) as well as dialectical principles. Short debating speeches, on the other hand, take their form entirely from dialectic and closely resemble interventions in university disputations. While the restrained style predominates in both kinds of speech, all the speakers employ amplification - adding detail or impressive language for emphasis - to mark important passages and to drive home arguments. Some speakers, especially later in the reign, cultivate a more elevated style throughout. Historical examples play a crucial role in longer speeches, with government speakers developing the contrast between Elizabeth's government and her inheritance from Mary, while other orators cite biblical and classical histories. Proverbs and moral sentences are very prominent in all types of speeches. Many arguments are also elaborated with commonplaces and lively descriptions. Several speakers use rhetorical principles to elaborate an individual ethos, or a persona, as a means of persuasion.

A rhetorical approach may also enable us to rethink some questions about the political function of the Elizabethan Parliament and in particular about the significance of opposition to the Privy Council line. Since the 1980 s, revisionist historians have questioned the importance of Parliament, arguing that the House of Commons was essentially powerless because the queen could always reject legislation of which she disapproved. Sir Geoffrey Elton took the view that most parliamentary speech was "empty words," devoid of impact on policy or legislation. Where Sir John Neale had overemphasized parliamentary opposition and misidentified its components, Elton denied it any role. But the fact that opposition to the Privy Council line was expressed and recorded in journals and that councillors took pains to reply to objections suggests that it had greater significance than Elton allows. ${ }^{3}$

2. By 1593, a majority of MPs had attended either university or the Inns of Court or both. Most of the rest would have attended grammar school or had private turors. See T. E. Neale, The Elizabethan House of Commons (London, 1949), 290-95. For biographies of MPs, see P. W. Hasler, The House of Commons, 1558-1603, 3 vols. (London, 1981). On rhetoric and dialecric in Tudor universities, see L. Jardine, "The Place of Dialecric Teaching in Sixteenth-Century Cambridge," Studies in the Renaissance 21 (1974): 31-62; J. McConica, ed., The Collegiate University, vol. 3 of History of the University of Oxford (Oxford, 1986);

L. D. Green, John Rainold's Oxford Lectures on Aristotle's Rhetoric (Newark, N.J., 1986), 13-23; and

D. R. Leader, History of the University of Cambridge, vol. 1 (Cambridge, 1988), 95-107, 117-38, 332-48.

3. G. R. Elton, The Parliament of England, 1559-1581 (Cambridge, 1986), 16-39, 125-26, 154-68, 321-29, 347-54, 377-79. Elton twice dismisses rhe queen's speeches as "verbiage" or "empty words" (pp. 362, 374). J. E. Neale, Elizabeth I and Her Parliaments, 2 vols. (London, 1953-57), 1:91-92, 101-4, 137-51, 193-207, 
Rhetorical theory explains that a speech may indeed have other purposes besides persuasion, but such words were far from empty. A speaker may retell narratives and develop arguments that the audience already accepts in order to recall and celebrate shared history and interests. ${ }^{4}$ Speakers may employ amplification and heightened style to demonstrate skill and observe decorum rather than to move an audience to a course of action. Many of the parliamentary speeches that survive function in a way that is as much ceremonial as persúasive, as I show below. By the same token, ritualized exchanges of compliments at the opening or closing of Parliament could be framed to convey real political messages. The distinction between display and persuasion is highly permeable in the discourse of the Elizabethan Parliament. Rhetorical analysis thus helps us rediscover the meaning of parliamentary speech.

A rhetorical approach enables an understanding of the effects of verbal contention that historians have rarely explored to date. Strongly expressed opposition sometimes had the effect of uniting consensus against itself (when, as we shall see, Arthur Hall defended the duke of Norfolk and when Peter Wentworth attacked the queen). During parliamentary debate, unwelcome views could be expressed and disagreement maintained. On rare occasions, members expressing opposition had the satisfaction of seeing their views incorporated in legislation or of finding that the queen shared their objections to a proposed course of action. More often the Privy Council line was upheld, sometimes after long debate. Replies from the powerful to the weak may appear to be a matter of observing proprieties, but they also indicate that members of Parliament expected their views to be listened to and that Privy Councillors found it worthwhile to provide answers and counterarguments.

Elizabethan parliamentary speeches also raise some more general political and ethical issues. Members argued about whether there were limitations on the freedom of speech allowed to them - for example, whether they could raise issues that the queen regarded as outside their competence, or whether they were obliged to listen to views repugnant to the majority. Grammar school textbooks and popular works of moral philosophy prepared parliamentarians to consider

and passim. For accounts of the controversy, see M. A. R. Graves, The Tudor Parliaments (Harlow, England, 1985), 1-18; Norman L. Jones, "Parliament and the Governance of Elizabethan England: A Review," Albion 19 (1987): 327-46; and David Dean, "Revising the History of Tudor Parliaments," Historical Journal 32 (1989): 401-11. J. D. Alsop attacks details of Elton's account in "Reinterpreting the Elizabethan Commons: The Parliamentary Session of 1566," Journal of British Studies 29 (1990): 216-40.

4. Whereas classical authorities regarded epideictic rhetoric mainly as a matter of writing speeches of praise or blame (Aristotle, Rhetoric, 1366a23-67a38; Rhetorica ad Herennium, III.6.10-8.15), twentieth-century theorists of rhetoric have emphasized its role in creating and unifying communities. See C. Perelman and L. Olbrechts-Tyteca, The New Rhetoric (Notre Dame, Ind., 1969), 47-59; and K. Burke, A Rhetoric of Motives (Berkeley, Calif., 1969), 35-59. 
questions about the nature of good counsel and the political function of arguing out opposed positions. ${ }^{5}$ Parliament often faced conflict between arguments based on religious or ethical principles and more pragmatic responses offered by those with responsibility for, and experience of, conducting government business.

Elizabethan parliamentary speeches survive in two kinds of record. ${ }^{6}$ Men such as Nicholas Bacon collected and polished the texts of their speeches as examples of eloquence. Also, members of Parliament serving particular political interests wrote journals summarizing daily proceedings. These two types of record draw attention to two different kinds of parliamentary intervention: the long formal speech (recorded apparently verbatim in personal collections and summarized at length in the journals), delivered by a government speaker, often on a formal occasion; and the shorter argumentative intervention in reply to a proposal or to a previous speaker (which appear only in the journals, where their arguments are summarized briefly). ${ }^{7}$ At the opening of Parliament in 1571 , after the Speaker's petition for freedom of speech, Sir Nicholas Bacon replied

that her Highnes thinketh it not meet that any sholde have further lybertie to speke or talke yn that Howse of any matter other then that which is there to be proponed, and that they should leave to talk rhetorice and speke logice, to leave longe tales which is rather an ostentacion of wytt then to any effecte, and to deale with these things as there were to be proponed: that goinge effectually to the matter they might dyspatche that they were sent for and that they might the souner returne home. ${ }^{8}$

Bacon argues that the dialectical form of debate will promote the conduct of parliamentary business better than rhetorical ostentation. ${ }^{9}$ His response suggests

5. Good counsel and the need for frankness of speech are major topics in Sir Thomas Elyot's The Boke named the Governour (London, 1531), printed eight times in the sixteenth century (especially in bk. 3, chaps. 28-30), and in such best-sellers as Lord Berners's Golden Boke of Marcus Aurelius (London, 1535), which was printed fifteen times; and William Baldwin's $A$ Treatise of Moral Philosophy (London, 1547), printed seventeen times. I discuss this topic in more detail in Elizabethan Rhetoric. See also John Guy, "The Rhetoric of Counsel in Early Modern England," in Dale Hoak, ed., Tudor Political Culture (Cambridge, 1995), 292-310.

6. T. E. Hartley, ed., Proceedings in the Parliaments of Elizabeth I, 3 vols. (Leicester, England, 1981-95). On the incompleteness of the record, see Hartley, Elizabeth's Parliaments: Queen, Lords, and Commons, 1559-1601 (Manchester, 1992), 8-9.

7. See, for example, the anonymous journal for 14 and 15 May 1572 (Proceedings, 1:319-26), which gives the long introductory speech of Thomas Wilbraham and then a terser report of the arguments and replies of the debate.

8. Ibid., 1:244.

9. Whereas reports of Bacon's introductory speeches record elaborate oratory, his replies to petitions are always reported as summaries of points made followed by answers to each point; see, for example, ibid., $1: 42-43,77-79,127-28,171-72,199,244-45$. 
that the distinction between long ceremonial speeches and brief interventions in debate may have been a parliamentary expectation.

In this article I shall illustrate the characteristics and structure of each type of discourse by analyzing one example of a long speech recorded verbatim and one example of a passage of summarized debate. Then I shall consider the means of persuasion and style (thus the first sections of the article will correspond to the rhetorical categories of dispositio, inventio, and elocutio). Then I shall discuss the related issues of opposition, free speech, and honest counsel, which form a contested context for parliamentary oratory, concluding with an analysis of the very special use Queen Elizabeth made of her own addresses to Parliament.

\section{Sir Nicholas Bacon's Speech for the Opening of Parliament 1571}

Sir Nicholas Bacon's commitment to the humanist program of rhetorical education is well established by the part he played in the founding of Redgrave Grammar School and by his reforms of the curriculum at Bury St. Edmunds and St. Albans. In 1561 he submitted to the secretary of state, Sir William Cecil, a plan for providing a better education for the wards of court and in 1574 he donated seventy volumes from his library to Cambridge University. ${ }^{10}$ In The Arte of English Poesie, Puttenham reports, "I have come to the Lord Keeper Sir Nicholas Bacon, and found him sitting in his gallery alone with the works of Quintilian before him, in deede he was a most eloquent man."11

Bacon's speech as Lord Keeper at the opening of Parliament on 2 April 1571 survives both in a full text in his own collection of speeches and in the reports of two journals. ${ }^{12}$ It is worth analyzing at length for what it reveals about the sometimes paradoxical relation between ornament and argument, plainness and elaboration. The Lord Keeper's speech, delivered to both Houses of Parliament in the presence of the queen, was part of the ceremony of the state opening of Parliament. It aimed to explain why the queen, on the advice of her Privy Council, had chosen to summon Parliament. ${ }^{13}$ In 1571 , the main reason for calling

10. R. Tittler, Nicholas Bacon: The Making of a Tudor Statesman (London, 1976), 58-61.

11. G. Puttenham, The Arte of English Poesie (London, 1589), 117. Compare B. Jonson, Discoveries (1641), ed. G. B. Harrison (London, 1922; reprint ed., Edinburgh, 1966), 37.

12. The very full report in the anonymous journal provides a close and reliable record of all the main points made in Bacon's text but adds a section on the importance of the head (by analogy to the body) and places the reasons for the lack of money ( $3 \mathrm{~b}_{2}$ in the diagram, p. 30 , below) before the benefits the realm has received ( $\left.3 b_{1}\right)$. Hooker reports a passage about money as the sinews of the state that appears neither in Bacon's text nor in the anonymous journal. Perhaps Bacon spoke a passage comparing the state and the body that he dropped from his revised text, or perhaps Hooker added an appropriate embellishment of his own; Proceedings, 1:182-87, 195-97, 243.

13. Neale, House of Commons, 340-41; Elton, Parliament, 29-32. 
Parliament was to raise revenue. ${ }^{14}$ Bacon begins his speech with sentiments and phrases that were usual on such occasions:

The Queene's most excellent Majestie our most dread and gracious soveraigne Lady haveinge comaunded me to declare unto yow the causes of your callinge and assembly at this tyme, which I meane to doe as briefely as I can, leade thereto as one very loath to be tedeous to her Majestie, and alsoe because to wise men and well disposed (as I iudge yow be) a fewe wordes doe suffice. The causes be cheifely two: th'one to establishe or dissolve lawes as best shall serve for the good governance of the realme, th'other soe to consider for the Crowne and state as it may be best preserved in the time of peace and best defended in the time of warre, accordinge to the honour due to it. ${ }^{15}$

The first sentence is a formula. In 1563 , on the same occasion, Bacon had said, "The Queene's most excellent Maiestye, our most deare and gratious soveraigne Ladye, hath given me in commaundement to declare unto you the causes of the summons of this assemblye for a parliamente. .. "16 In comparison with Bacon's other speeches at the opening of Parliament, however, his exordium in 1571 really is brief, omitting the elaborate statement of his unworthiness that is usual at the beginning ${ }^{17}$ and pausing only momentarily to explain that he can be brief because his audience is wise and well disposed (almost in the words of Rhetorica ad Herennium ${ }^{18}$ ) before proceeding to his "division," setting out the organization of the speech. The purpose of the Parliament is twofold: to establish laws and to consider the measures to be taken for the preservation of the state. Bacon's expression becomes a little more elaborate as he goes on to talk about ecclesiastical laws:

And because in all counselles and conferences first and cheifely there should be sought the advancement of God's honour and glory as the sure and infallible foundacion whereupon the pollicy of every

14. There is some evidence that Elizaberh resisted Cecil's suggestion that Parliament be summoned in 1570 because she still felt bruised by the parliamentary discussion in 1566 of the issue of the succession; Neale, Parliaments, 1:177-79.

15. Proceedings, 1:183.

16. Ibid., 1:80.

17. Compare ibid., 1:3 (1559), 1:80 (1563).

18. Rhetorica ad Herennium, I.4.6-5.8. The anonymous Rhetorica ad Herennium was the most widely used manual of classical rhetoric in the Middle Ages and the Renaissance. 
good publique weale is to be erected and builte, and as the straight line whereby it is principally to be directed and governed and as the cheife piller and buttres wherewith it is continually to be sustained and maintained, therefore, for the well performeinge of the former touchinge lawes yow are to consider first whether the ecclesiasticall lawes concerninge the discipline of the Church be sufficient or noe, and yf any wante shalbe founde to supply the same[.]

This paragraph is organized in the logical form of an enthymeme: because God's honor and glory come first, therefore we should first consider ecclesiastical law. This is elaborated with a persistent doubling of epithets (counsels and conferences, first and chiefly, honor and glory, sure and infallible) and a series of architectural images (the foundation, the straight line) and, combining the two techniques, "the cheife piller and buttres." In view of the fact that religious discussion (of a kind not always welcome to the government) took up a great deal of parliamentary energy in 1571, the question has been raised as to whether Bacon, whose private sympathies were strongly Protestant, was here providing some kind of hint to the more radical Protestants in Parliament, or responding to the Reforming sermon that both Houses had just heard Edwin Sandys deliver in Westminster Abbey. ${ }^{19}$ However, all of Bacon's opening speeches contain some reference to laws for the church, and this one even repeats some of the phrases with which he had introduced the topic of religious change in the more obviously significant speech of 1559 :

[F]irst and chieflie there should be soughte the advauncemente of Gode's honor and glory as the suer and infallible foundacion whereupon the pollicie of every good publique weale is to be erected and builte, and as the straite lyne whereby it is wholly to be directed and governed, and as the chiefe pillar and buttreuxe wherewith it is continually to be sustayned and maynteyned. ${ }^{20}$

19. See R. Tittler, Nicholas Bacon, 50-52, 91-92; P. Collinson, Godly People (London, 1983), 134-53, "Sir Nicholas Bacon and the Elizabethan Via Media"; and Neale, Parliaments, 1:185-86. Neale thought that Bacon was anticipating "unofficial moves for reform" and that the real point of the passage was the later reference to the leading role to be taken by the bishops: "Thereof the greatest care ought to depend of my Lordes the Bishops" (Proceedings, 1:183).

20. Proceedings, 1:34. The repetition of passages between speeches collected in the same manuscripts might be a reason for thinking that Bacon did not rewrite his speeches prior to collecting them, since such repetition would be an obvious thing to remove in revision, whereas the audience of the earlier occasion would not remember language from a speech delivered several years before. 
The most likely explanation is that Bacon needed to make some reference to strengthening the law on religion and found that he could hardly do better than repeat the ringing phrases of his earlier speech. ${ }^{21}$

At the beginning of his opening oration of 1571 Bacon is very restrained in his use of ornament, moving rapidly to set out the tight logical arrangement of his speech:

\section{Structure of the Oration}

no. of lines

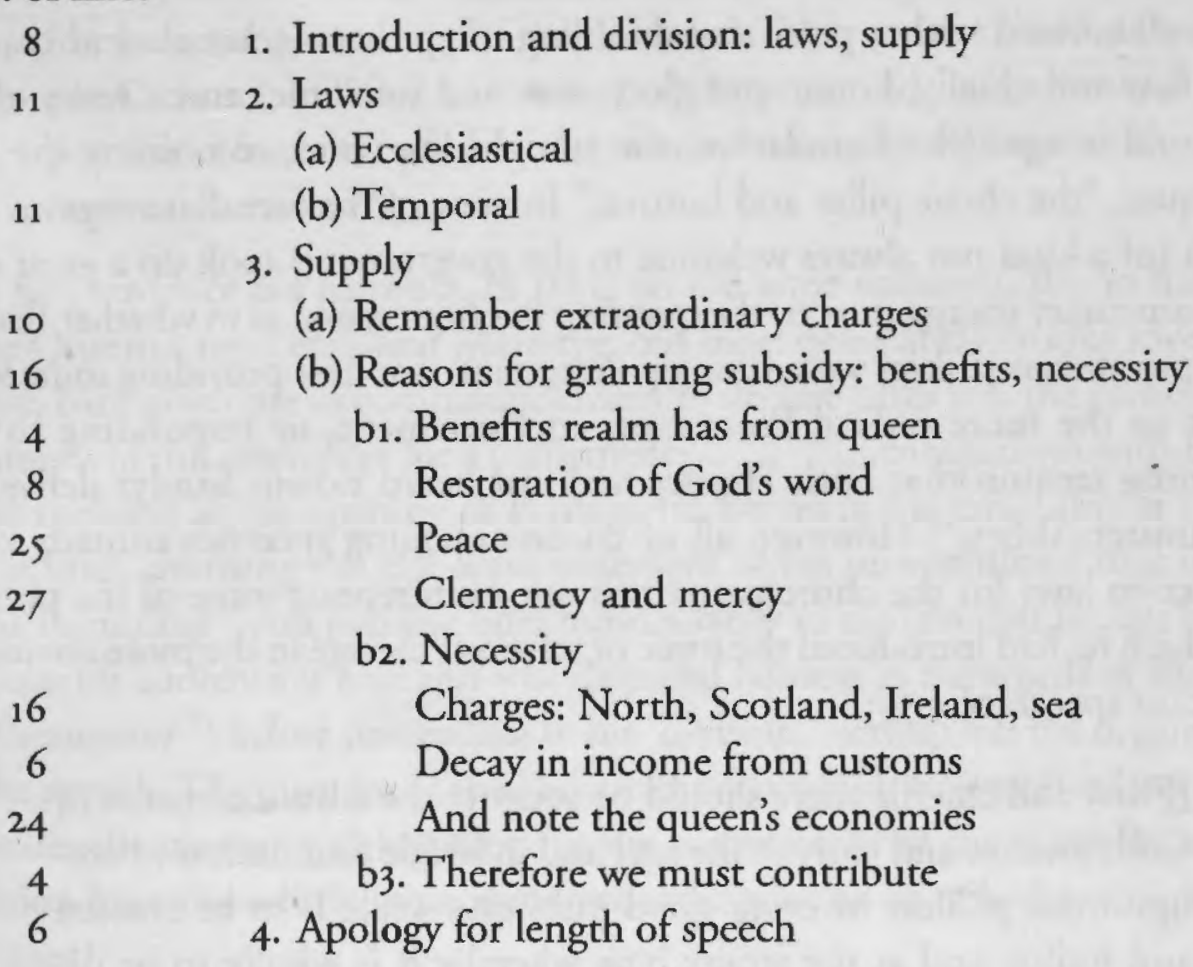

The speech is organized as a series of divisions. Parliament is concerned with laws and supply. Laws are ecclesiastical or temporal. Supply must be granted because of benefits and necessity. Bacon discusses benefits in some detail, necessity in rather less. Before closing he anticipates an objection by insisting on the frugality of the queen's expenses. He ends on a low note, with a brief conclusion and an apology. The emphasis on successive division makes this speech more like a medieval thematic sermon, a scholastic determination, or even a Ramist treatise in structure than the four-part classical oration that Bacon's interests might have

21. The very full report of the anonymous journal for 1571 makes no reference to religion, while Hooker in his report notes in only two words that "trew religion" was one of the three points of the speech, devoting most of his report to the queen's need of money; Proceedings, 1:195-97, 243. 
led us to expect. There is no peroration to speak of, but both the techniques of the introduction and the use of a reply to objections indicate some influence of ideas about disposition from classical rhetoric. ${ }^{22}$ While the plan sets out a series of divisions that provide a structure for all the activity of the Parliament, the weight of the speech is placed on the benefits the realm has received, the charges the queen has to bear, and the removal of the objection of wastefulness. In form Bacon restates the general duties of Parliament, as he must for this occasion, but the content of the speech is mainly directed to the financial issue.

Bacon introduces the question of supply by reminding his audience of the number of extraordinary charges on the Crown and of the principle that such charges have to be met by extraordinary revenue. Then he appears to hesitate, in order to draw on the good will of his audience:

\section{But here I rest greatly perplexed whether I ought to open and re- member unto yow such reasons as may be iustly produced to move you thankefully and readily to grante this extraordinary reliefe or noe. I knowe the Queen's Majestie conceaveth soe great hope of your prudent foreseeing what is to be don, and of your good willes and readines to performe that which by prudency yee forsee, that fewe or noe perswasions at all are needefull for the bringinge this to passe. ${ }^{23}$}

He begins by apparently artlessly setting out the dilemma he faces as a speaker. The hesitation gives him the opportunity to build up the audience's sense of its own prudence and to draw out the queen's favorite theme of her special relationship with her subjects. This is noticeably subtler and more audience friendly than the tone he adopted in 1559 , when he instructed members of Parliament about the manner in which they were to debate. ${ }^{24}$

22. The classical oration can be regarded as having four parts: introduction or exordium, narration, argument, and peroration. The section on argument was divided into proof, of one's own case, and refutation, of what one's opponents had said; Aristotle, Rhetoric, III, 1414azo-b18. Since, unlike Bacon, most grammar school pupils would not have read a textbook of the whole of rhetoric, it is worth pointing out that both of these "classical" elements were available in the letter-writing treatises and progymnasmata that were widely studied in grammar schools.

23. Proceedings, 1:184.

24. Ibid., 1:34-35: "And therewith that you will also in this your assemblye and conference clearely forbeare and, as a greate enemye to good councell, flee from all manner of contentious reasoninges and disputacions and all sophisticall, captious and frivolous argumentes and quiddities, meeter for ostentation of witt then consultacion in weightie matters, comelyer for schollers then for counsellors, more beseeminge for schooles then for parliament howses; besides that commonly they be greate cause of much expence of tyme and breed few good resolucions." 
Once the queen's expectation has been established he returns to his own person to make the arguments-although the queen thinks you are so wise and so well disposed as to need no persuading, still to fulfil the duties of his office I will add a few arguments. From this rhetorical highlighting of his own persona and the response expected of his audience he moves very quickly back into the restrained, dialectical manner:

True it is that there be two thinges that ought vehemently to move us franckly, bountifully and readily to deale in this matter; the former is the greate benefittes that we have received, the seconde is the necessity of the cause. Yf we should forgette the former we are to be chardged as most ungrate and unthankefull, and the forgettefúllnes of the seconde doth chardge us as uncarefull of our owne liveinges and libertyes, and of our lives: the former moveth by reason and the seconde urgeth by necessity. ${ }^{25}$

Bacon justifies his division in argumentative terms: if you neglect benefits you are ungrateful; if you ignore necessities you are taking risks with life and liberty. Nonetheless, the patterning and repetition make the argument appear to function more as display than persuasion. There is also an unmistakable allusion to rhetorical teachings about deliberative oratory, in which "benefits" and "necessity" are two of the standard topics through which one expects to persuade an audience in a political speech. ${ }^{26}$ In the following paragraph, Bacon elaborates a commonplace in praise of peace through techniques that are even more obviously rhetorical. He enriches the style of this passage with doubling, rhetorical question, metaphor, isocolon (phrases of equal length in series), ploce (repetition of individual words), and synoiceosis (linking of contraries):

The seconde is the inestimable benefitte of peace dureinge the time of tenn wholl yeares raigne togeither and more. And what is peace? Is it not the richest and most wished for ornamente that pertaines to any publique weale? Is not peace the marke and ende that all good govermentes directes their actions unto? Nay is there any benefitte, be it never soe greate, that a man may take the full commodytie of without the benefitte of peace, or is there any soe litle

25. Ibid., 1:184.

26. See De inventione, II.56.168-58.175; and Thomas Wilson, The Art of Rhetoric (1560), ed. P. Medine (University Park, Pa., 1994), 71, 79, 144. The topics of "the honorable" and "the necessary," with many subtopics on the individual virtues, are discussed at length in Cicero's De officiis, one of the standard grammar school texts. 
commodytie but thoroughe peace a man may have the whoall fruition of it? By this we generally and ioyfully possesse all, and without this generally and ioyfully possesse nothinge. ${ }^{27}$

Finally, peace is praised through consideration of its opposite, war, which is absent from Britain but alarmingly present in the neighboring states; the miseries of our neighbors enable us to understand the blessings we possess. Within the context of a restrained, logical speech, this section achieves a certain stylistic flourish, but no one would call it a purple passage. Nonetheless, it functions more as a demonstration of rhetorical skill than as forceful persuasion. Bacon is fulfilling the obligations of his assignment, using the skill he would be expected to show, elaborating a commonplace out of an argument his whole audience will be happy to agree with.

Rather than dwelling on the inadequacy of the ordinary income available (to which he gives a mere six lines), Bacon prefers to answer an anticipated objection: Whereas ordinary princes create financial problems for themselves by extravagant spending, our queen has cut down on expenses and contented herself with what is necessary. He amplifies this idea with a series of patterned phrases in which the extravagant delights of unnamed other princes are contrasted with Elizabeth's restraint and practicality:

To discend in some perticulers, what neede I to remember to yow howe the gorgeous, sumptuous, superfluous buildinges of times past be for the realme's good by her Majestie in this time turned into necessary buildinges and uphouldinges; the chardgeable, glitteringe glorious triumphes into delectable pastimes and shewes, the pompes and solempe ambassadores of chardge into such as be voide of excesse and yet honorable and comely. This and such like were draweinge draines able to dry upp the floweinge fountaines of any treasurye, these were quilles of such quantity as would soone make the many pipes to serve in tyme of necessity such an expendit [as] is hardly satisfied by any collector; and yet those imperfections have bin comonly princes' peculiers, especially younge. One free from these, rara avis etc. And yet (God be thanked) a phenixe, a blessed birde of this brood God hath blessed us with. ${ }^{28}$

27. Proceedings, 1:184-185. Although Bacon does not quote it, the maxim from the grammar school Latin reader Sententiae pueriles "omnia bona pace constant" (sig. A8v in the London 1639 edition) can certainly be thought of as underlying this passage.

28. Proceedings, 1:186-187, with one alternative reading from the collation ("draines" for "dames" and one addition, in square brackets). "Quille" here means "water-pipe"; $O E D$, sense 2. 
The initial sentence is a rhetorical question, with a hint of occupatio (I have no need to tell you ...). This is elaborated with parison as well as alliteration, when "gorgeous, sumptuous, superfluous buildinges of times past" is set against "in this time turned into necessary buildinges and uphouldinges." Bacon is chiefly contrasting the vainglorious and excessive expenses of other princes with the useful and honorable spending of the queen. In the second sentence the prodigality of other princes is amplified through metaphor and alliteration before he returns to the comparison. Such is the norm; our "prince" is unique. The synonym of the phoenix is decorated with alliteration and polyptoton (in the repetition of "blessed" with different emphasis and different grammatical functions).

This passage contains far more verbal ornament than the rest of the speech, but the effect of this amplification is not the arousal of emotion in the service of persuasion that was the original purpose of amplification, according to the rhetoric manuals. ${ }^{29}$ Rather, it serves to compliment the queen, and perhaps also to gloss over the awkwardness involved in balancing considerations of money and honor-praising her parsimony while at the same time asking for money. By comparison the conclusion of the speech is plain in the extreme:

Here I would put yow in mynde of extraordinary chardges to come which in reason seemes evident, but soe I shalbe over tedeous unto yow and frustra fit per plura quod fieri potest per pauciora. And therefore here I make an ende doubtinge that I have tarried yow longer then I promised or meante or perchance needed (your wisedomes and good inclinacions considered), but yow knowe thinges are to be don both in forme and matter; and my trust is, yf I have stayd, I may be warranted by either or by both, and that yow will take it in good parte. ${ }^{30}$

The plainness of the ending partly serves to establish an attractive humility in relation to the wisdom and understanding on which he compliments his audience, but such simplicity also responds to the occasion. Because there is no immediate action or decision in prospect, there is no purpose here in amplification and emotional manipulation (which the classical manuals of rhetoric regarded as an

29. Rhetorica ad Herennium, II.30.57-49; Cicero, De inventione, I.53.100; Quintilian, Institutio oratoria, VI.2.20-24, VIII.4. Erasmus acknowledges the connection between amplification and the manipulation of emotions but he insists that skill in amplification has other purposes too; Erasmus, De copia, in Opera omnia, I-6, ed. B. Knott (Amsterdam, 1988), 32-34, 218-220, 276-79 (translated in Collected Works of Erasmus, vol. 24 (Toronto, 1978), 301-2, 592-95, 654-57.

30. Proceedings, 1:187. 
essential part of the peroration). ${ }^{31}$ The comment of the anonymous journal ("surely noe wordes might suffice or skill serve to containe the tennour of that speech, if it shoulde or could be toulde with due report, even as I thinke the hearers wholy in conscience did acknowledge right well") ${ }^{32}$ suggests that the audience was satisfied by Bacon's display of eloquence. Throughout, Bacon aims more at clear exposition than emotional manipulation, trusting his audience to draw the conclusion; yet he permits himself to compose a commonplace on peace and an amplification of the benefits the country has derived from its monarch. These elements, which could have formed part of an epideictic oration (for example, a speech in praise of Queen Elizabeth), connect the logically organized speech with its celebratory occasion. Rhetorical analysis reveals the way in which a relatively unornamented speech could accommodate more elaborate elements, and that it could be received as eloquent and skillful.

Nicholas Bacon's introductory speeches appear to present a general pattern for formal speeches on the government side. ${ }^{33}$ Such speeches usually begin with a formula expressing the queen's command and an apology for the orator's unfitness for his task. After a short attempt to win the good will of the audience, in the manner suggested in Rhetorica ad Herennium, ${ }^{34}$ the speaker makes a series of divisions to set out the shape of the oration. All the speakers dwell on the achievements of the government before attempting to justify the taxation they request. As chancellor of the exchequer, Sir Walter Mildmay ${ }^{35}$ introduced his speech for supply in 1576 even more briefly than Bacon had, elaborating his announced threefold structure with a series of arguments about the queen's financial diffculties and the mistakes of her predecessors. ${ }^{36}$ Government speakers frequently

31. Quintilian, Institutio oratoria, VI.1.1; see also the references in n. 29, above.

32. Proceedings, 1:197. Neale discusses this speech in Parliaments, 1:186-87.

33. They may even have been used as a structural model by later orators. The exordium of Sir Christopher Hatton's speech at the opening of Parliament in 1589 is written in a far more elaborate style but it covers exactly the same ground as Bacon's; Proceedings, 2:414.

34. Rhetorica ad Herennium, I.4.7-5.8.

35. On Mildmay's educational interests and his foundation of Emmanuel College, see S. E. Lehmberg, Sir Walter Mildmay and Tudor Government (Austin, Tex., 1964), 222-31, 235. Among the books he gave to Christ's College and Emmanuel College were complete edirions of Aristotle, Nizolius's dictionary of Ciceronian Lacin, and Rudolph Agricola's De inventione dialectica. Neale discusses this speech in Parliaments, 1:346-48. Hartley describes the subsidy speech in Elizabeth's Parliaments, 38-40. Biographies of members of Parliament, including Mildmay, who first attended in Elizabeth's reign, appear in Hasler, House of Commons.

36. Mildmay divided as follows:

And that you may the better iudge of that which I shall propone, it is requisite that I putt you in remembrance:

1. first how the Quene found the realme,

2. next how shee hath restored and conserved it,

3. and thirdly how we stand now. 
forestall objections by comparing the queen's parsimony with the profligacy of other princes. ${ }^{37}$ The refutation of objections is usually followed by a brief summary and an apology for the time the speech has taken. ${ }^{38}$ That this pattern was a parliamentary expectation is confirmed by Archbishop Heath's use of successive divisions and his apologetic conclusion in his speech against the Bill of Supremacy in $1559 .{ }^{39}$ It is very like the basic pattern we discovered in Bacon's speech:

\section{Introduction and division \\ Three points (more or less) \\ Refutation of objections \\ Summary and apology}

This pattern was capable of further adaptation but was rarely abandoned. ${ }^{40}$ For example, Sir Christopher Hatton's opening speech in 1589 begins by observing Bacon's pattern, but he soon adds to his model, arranging the argumentative section of the speech around two lengthy parallel accounts of the past misdemeanors and present plans of the Catholic powers. ${ }^{41}$ When he replaces the summary and apology with an elaborate peroration, this results in an overall structure closer to (though certainly not identical to) the four-part oration recommended in the classical manuals of rhetoric: ${ }^{42}$

\section{Hatton's speech}

Introduction and division

Past dangers from Catholics

Present dangers: Puritans and Catholics

Conclusion: remedies
Classical four-part oration

Exordium

Narration

Proof and Refutation

Conclusion

Touching the first, no man can be ignorants that our most gracious Quene, at her entry, found this noble realme, by reason of the evill government preceding, miserably overwhelmed with popery, dangerously afflicted with warr and greivously oppressed with debt." (Proceedings, 1:440; for the financial arguments, see 1:443-44)

37. Proceedings, 1:186, 443, 506. In later Parliaments there is more emphasis on the contributions that the queen has made to the costs of war from her ordinary income than on the frugality of her court.

38. Ibid., 1:77, 187, 444. The apologies are less frequent in the later Parliaments.

39. Ibid., 1:12-17.

40. Peter Wentworth's 1576 speech on parliamentary liberty (see text at $n .94$, below) also develops from extensive divisions, characteristic of formal parliamentary speeches on the government side, into a detailed vituperative account of incidents from the Parliament of 1572; ibid., 1:425-34.

41. The accounts are parallel because they both have successive sections on the English seminary priests, Pope Sixtus V, and Philip II of Spain.

42. The parts of the oration are discussed by Aristotle, Rhetoric, 1414azo-b18; Cicero, Partitiones oratoriae, I.4; Rhetorica ad Herennium, I.3.4; and Quintilian, Institutio oratoria, III.9.1-7. Some authorities recognize the same pattern but regard it as having more parts because they divide division from narration and/or proof from refutation; see Peter Mack, Renaissance Argument (Leiden, 1993), s n. 7. 
Hatton uses the peroration, as the classical manuals suggest, ${ }^{43}$ to summarize the argument, to turn to the audience, and to recommend his solution with the greatest possible emotional force. His argument is a hypothetical syllogism whose conclusion is delayed by a rhetorical question. He uses the form to summarize the intentions of the state's enemies with a series of if-clauses, amplifying the consequences of their intentions by going into detail:

If, then, my Lords, our enemies, so manie and so mightie, in so lewde a cause as theirs is, have combined themselves together against us, yf in the respects before mencioned thei are fullie resolved to set up their rests either nowe or never to subdue us, either nowe to conquere us or to lay themselves open to be conquered of others, $y f a c$ cordinglie thei ioyne together and are in devisinge all the waies and meanes whereby thei maye be able to execute their furie upon us, to overthrowe our religion, to depose hir Majestie, to possesse our lande, and with all kinde of crueltie to murther everie one of us; what care then I say, my Lords, ought we to have in so holie, so iust, so honourable, so profitable and so necessarie a quarell to ioine together, to foresee these daungers, to provide for them and to set up our rests either nowe or never to be able to withstande them ${ }^{44}$

Hatton's lengthy question emphasizes the topics of deliberative oratory (holy, just, honorable, necessary) and expands on the general themes of unity, foresight, and determination. And the speaker summarizes his key arguments before arousing the emotions of his audience, as the classical peroration was expected to do. But there is also a way in which the argumentative form here is decorative once again, setting up a balance between the threats and the response required, providing an elegant form for restating the main shape of the speech. Putting the conclusion in the form of a question turns the speech toward the audience, asking them to reflect on their role in relation to these events. Hatton's peroration clearly depends on rhetorical principles, most obviously on those advanced by Quintilian and on a study of Cicero's perorations, undertaken in the university curriculum. For other speakers, though, an initial gesture toward conciliating the audience leads on to a dialectically organized speech. For them the letter-writing manuals could have provided sufficient guidance. ${ }^{45}$

43. Rhetorica ad Herennium, II.30.47-31.50; Cicero, De inventione, I.52.98-56.109; Quintilian, Institutio oratoria, VI.1-2.

44. Proceedings, 2:423-24; my emphases.

45. For example, Erasmus, De conscribendis epistolis, ed. J. C. Margolin, Opera omnia, I-2 (Amsterdam, 1971), 316; trans. C. Fantazzi, Complete Works of Erasmus, vol. 25 (Toronto, 1985), 74. 


\section{The Debate on Supply, 1593}

In parliamentary debate, positions unwelcome to the queen and her councillors could be expressed and maintained, and councillors needed to respond to the arguments made in order to achieve their objectives. Debate in the Elizabethan Parliament is usually summarized by the journal writers as a relatively calm conflict of opposing views. The journals generally record the main arguments of the speakers and indicate whether they supported or opposed a proposal. At times the grammar of the report, the detail of the vocabulary, or the patterning of the expression suggest that the orator's actual words have been recorded. Since Elizabethan schoolboys were trained to record phrases from their reading and from sermons they heard for reuse in their own compositions, it should not surprise us that the journal writers might at times record parliamentary speech verbatim. ${ }^{46}$

In 1593 there was a protracted and difficult debate about the size and timing of the subsidy, an especially sensitive area for the government. Usually the bill for subsidy was the occasion for some of the more elaborate formal oratory on the government side. While legislation on the subsidy could be delayed so as to allow time for other bills to be passed, it was not normally opposed. But in 1593 there was an argument, both about the roles of the two Houses and about the actual taxation proposed. As a result of an intervention in the Lords by Lord Burghley, who had demanded greater taxation than the Commons had hitherto offered, the two Houses were arguing over the broader question of who had the right to initiate discussion of subsidy. ${ }^{47}$ On 7 March, after a conference between Lords and Commons the previous afternoon, Sir Thomas Cecil's proposal of a scale and timetable for taxation intended to be acceptable to both Houses met with a series of counterproposals in the Commons. ${ }^{48} \mathrm{~A}$ committee debated the issue that afternoon and the following morning. In view of the parlous state of the queen's finances and the seriousness of the Spanish military threat, the councillors wanted the Commons to agree to the payment of three subsidies within a shorter time scale than was usual, three years or at most four. ${ }^{49}$ The journal reports the response of Francis Bacon, son of Sir Nicholas:

46. Indeed, two of the parliamentary journals appear to be collections of pithy sayings such as might be recorded in a commonplace book rather than records of the proceeding; see Proceedings, 2:105-27 (the

47. Neale, Parliaments, 2:298-307; Hartley, Elizabeth's Parliaments, 112-13; and Dean, Law-Making and Society
in Late Elizabethan England (Cambridge, 1996), 43-47.

48. Most texts of the anond (Canbridge, 1996), 43-47. corrects this to Sir Robert Cecil, which Seem Thomas Cecil as the proposer, and Neale concurs. One text

49. Proceedings, 3:104-8. 
Then Mr Francis Bacon assented to three subsedies but not to the payments under six yeares, and to this propounded three reasons which he desiered might be aunswered:

1. Impossibilitie or difficultie

2. Danger and discontentment

3. A better manner of supply then subsedye.

For impossibilitie the poore man's rent is such as they are not able to yeald yt, and the generall commonalty is not able to paie so much uppon the present. The gentlemen they must sell their plate and the farmers their brasse pottes before this wilbe payed. And for us we are here to search the wounds of the realme and not to skynne them over, wherfore wee are not to perswade our selves of their wealth more then it is.

The daunger is this. Wee breed discontentment in the people and in a cause of jopardie her Majestie's saftie must consist more in the love of her people then in their welth, and therfore not to geve them discontentment in paying theis subsedyes. Thus wee runne into perills; the first in putting twoe paymentes into one we make it a dubell subsedie, for it maketh $4 s$ in the pound a payment; the second is that this being graunted in this sort other princes herafter will look for the like, so we shall putt an ill president uppon our selves and to our posteritie. And in histories yt is to be observed that of all nations the English care not to be subiect, base, and taxeable.

The manner of supplie may be levie or imposition when need shall most require, so when her Majestie's coffers and pursse shalbe emptie they may be embassed by this meanes. ${ }^{50}$

The younger Bacon states his position on the subsidy very clearly at the beginning. Like his father he makes a prominent division into three reasons set out in his speech. Within the issue of impossibility, he divides between the poor, who cannot pay at all, and the better off, who cannot pay so quickly. Rather than backing these points up with quantitative arguments, he illustrates them with the emotion-rousing vignette of the householders selling their possessions to pay their taxes. ${ }^{51} \mathrm{He}$ uses a metaphor, expressed almost as a proverb, to drive home

so. Ibid., 3:109-10. I have adopted two variants from other sources recorded in Hartley's footnotes: "reasons" in line 2 and "care not" in line 21.

51. Bacon's view of this matter is quantitatively supported by David Dean, who notes that as a result of this triple subsidy and another agreed in 1597 the English were "more heavily taxed in the 1590 os than at any other time under the Tudors"; Law-Making and Society, 41-42. David Harris Sacks considers them less heavily taxed than their Continental contemporaries; see "The Paradox of Taxation: Fiscal Crises, 
this point. Parliament must investigate the wounds of the commonwealth, not hide them. Under "danger," he argues that the queen is in danger from the discontent that would arise from further taxation and that she needs the love of the people more than she needs their money. Though this argument may seem naive, it does respond to a position that the queen often takes up in her speeches, that she is more pleased with the love of her subjects than with the sums of money they offer her. ${ }^{52}$ Bacon divides the danger into two aspects: the excessive amount of the subsidy if two payments are combined, and the precedent additional subsidy establishes for future princes. He supports his argument about the danger of excessive taxation by referring to the lessons of the chronicles. ${ }^{53}$ Finally, he suggests that means other than subsidy should be found for providing for the queen's needs. ${ }^{54}$ Thus, although Bacon's announced structure is very clear, he supports his points with comparisons and historical instances rather than strong logical arguments.

Sir Thomas Heneage, who had taken a prominent part on the Privy Council's side in this controversy, follows Bacon's initial division in his reply. To Bacon's first point Heneage replies with brevity, zeugma (several predicates for a single verb), and point that one cannot regard taxation of the poor as impossible, since it has happened, or taxation of the better off as difficult, since it has frequently occurred. To the second point he argues that the people will not be discontented with the queen since they share her religion and are loyal to her. Then he turns to the necessity of the time, arguing that the swift payment of additional taxation is essential to the survival of the state. Although this argument responds to Bacon's implication that the queen needs money less than she does other forms of support, Heneage gives it the additional force of a separate point and distinguishes it by reiterating the issues of time, extraordinariness, and necessity. He concludes his argument with a maxim, "that in this case past examples might not lead us, but that the present danger should move us"ss - that is, rather than being led by past examples, people should be moved by present danger.

Parliament, and Liberty in England, 1450-1640," in P. T. Hoffman and K. Norberg, eds., Fiscal Crises, Representative Institutions, and Liberty in Early Modern Europe (Stanford, Calif., 1994), 7-66 at 48, 65-66. M. J. Braddick charts the increasing proportion of government expenditure met from taxation between 1590 and 1700 in Parliamentary Taxation in Seventeenth-Century England (Woodbridge, England, 1994), 2-14, relying for the sixteenth century on Penry Williams, The Tudor Regime (Oxford, 1979), 70-80.

52. David Harris Sacks, "The Countervailing of Benefits," in Hoak, Tudor Political Culture, 272-91; he discusses the exchange of love between monarch and subjects (pp. 284-88).

53. Mirror for Magistrates, for example, identified excessive taxation as one of the reasons for the collapse of Richard II's support; L. B. Campbell, ed., Mirror for Magistrates (Cambridge, 1938), 113-14.

54. In this opinion, too, Bacon has the support of modern historians; see J. Guy, Tudor England (Oxford,

1988), 381-85, relying mainly on F. C. Dietz, English Public Finance, 1485-1641, 2 vols. (Urbana, Ill., 1921).
55. Proceedings, 3:110. 
Later in the debate Burghley's son Robert Cecil returns to Bacon's points:

Yet I will speake to the particular partes, vizt. our povertie is not to be skinned but to be throughly healed; discontentment is to be feared; presidentes hearafter cannot be avoyded.

For the first, if we be poore yet at this tyme it must be considered we are in great danger, and then of twoe misscheifs we must choose the lesser. And therfore I would have this question after soe much discussinge banished the House.

The supposition of discontentment is without sence for it hath bin never hertofore, not is it liklie that now it wilbe.

For presidentes they never have bin perpetuall but beganne and ended with the causes, and as the cause grewe soe grewe the president.

In her Majestie's tyme yt is not to be feared that this president will ever doe us harme. ... This beinge out of feare we have noe reason to preiudice the best queene or king that ever came, for feare of a worse king then ever was. ${ }^{56}$

Cecil begins with a summary of the points he is going to answer, a practice that seems to derive from academic disputation, the main form of intellectual exercise and examination at Tudor universities. According to Robert Sanderson, the first duty of the respondent in a disputation was to repeat the argument of the opponent, before indicating whether he agreed or disagreed. ${ }^{57}$ This pattern of speech making helps keep debate focused and enables each speaker to locate his position in relation to others expressed.

Cecil's arrangement of the points is slightly different from both Bacon's and Heneage's. He repeats the metaphor with which Bacon expressed Parliament's obligation to respond to the state of the commonwealth. To poverty he opposes danger. On the basis of the ethical maxim that one must choose the lesser of two evils, he argues that taxes will have to be raised in spite of the difficulties this will create. The argument from discontent he simply rejects. On the issue of setting a precedent, he argues that precedents always depend on causes. In the queen's case he provides specific evidence that she does not accept taxes unless she needs them. Finally, Cecil declares that we should not risk losing the best monarch because we are worried about what a worse one might do. Unlike Bacon, Cecil is not eloquent but he is logical and forceful. He backs up his arguments with both

56. Ibid., 3:112-13. I read "this" for "thus" in line 13, following an alternative recorded in Hartley's notes.

57. R. Sanderson, Logicae artis compendium (Oxford, 1618), sigs. T3v-4r. This is the edition reprinred in facsimile with introduction by E. J. Ashworth (Bologna, 1985). 
maxims and historical evidence. In the event, the committee accepted his arguments and the House agreed to the payment of three subsidies in four years. ${ }^{58}$ Bacon paid for his intervention with a period of royal disfavor. ${ }^{59}$

Although it is likely that forms of pressure other than such disfavor could be applied to members of Parliament, ${ }^{60}$ especially those with aspirations at court, reports of speeches in debates show how much emphasis the parliamentary audience placed on outlining propositions and answering them. Although individual speakers sometimes made their points most effectively using rhetorical techniques (for example, comparisons or proverbs), the mainly dialectical mode of parliamentary speech recalled the expectations of academic disputations. This shared educational background may have been the most important reason that members of the Privy Council felt compelled to respond to arguments put to them by ordinary members of Parliament. ${ }^{61}$

Contributions to debate observed a purely dialectical structure. Speakers would summarize the points made by a previous speaker and would answer each point in turn, concluding with a statement of their position on the issue in question, sometimes backed up by an argument. The model for this form of debating speech and for the methods of refutation it employs (pointing out logical contradiction, distinguishing the ways words are understood, and so forth) is provided by the university practice of disputation.

Even some parliamentary ceremonies take the same dialectical form. When the Speaker petitions the queen for parliamentary privilege at the opening of Parliament, and when he thanks her and craves her pardon at the close, the Lord Keeper (or whoever is speaking for, and after consultation with, the queen) lists each of the points that has been made and replies to each in turn. The topics of both speeches are largely fixed but may be varied to convey political messages. At the opening ceremony in 1559 , Bacon glosses the agreement to freedom of speech "so as they be neither unmindfull nor uncarefull of their dutyes, reverence and obedience to their soveraigne." ${ }^{62}$ In 1571 , Bacon thanks the members of

58. Proceedings, 3:113-14. 59. Neale, Parliaments, 2:309; J. Spedding, The Letters and the Life of Francis Bacon, 7 vols. (London, 1861-74),
1:231-38.

6o. Neale suggests that such methods were used to persuade Robert Beale to change his mind about a precedent (Parliaments, 2:304-5); see Proceedings, 3:95, 98.

61. There may be some relation between the privilege of the university, which allows disputation of questions that would not be permissible elsewhere (for example, considering in the queen's presence whether monarchy was the best form of government), and the more restricted and more contested privilege of parliamentary free speech. As chancellor of Cambridge, Lord Burghley thought that certain ideas about presbyterianism could be discussed in an academic context. See A. F. Scott Pearson, Thomas Cartwright and Elizabethan Puritanism, 1535-1603 (Cambridge, 1925, reprint ed., Gloucester, Mass., 1966), 13-16, 34. 
Parliament for the subsidy, noting that some members have behaved in an arrogant way, ignoring the advice to avoid certain topics, which he gave at the beginning of the session. ${ }^{63}$

\section{Means of Persuasion}

Elizabethan parliamentary orators drew their arguments from a range of sources: from history, from personal experience, and from the topics of deliberative rhetoric. Sometimes these arguments functioned to decorate the speech or to win the audience's favor, while the persuasive weight of the speech in fact rested on resources and techniques usually regarded as more decorative-for example, proverbs, commonplaces, and fictional narratives.

Historical arguments played a large role in the longer speeches, but they did not necessarily function to persuade. Nicholas Bacon, Hatton, and Mildmay all gave considerable space to accounts of the queen's achievements in reforming religion, maintaining peace and security, and promoting wealth. They all emphasized a temporal contrast between the remote past of the failures of Mary's reign, the immediate past of Elizabeth's successful reforms, and the present, in which the country was threatened by the Catholic powers. Where the Tudor myth, as we find it in chronicles, dwells on the anarchy of Richard III's reign to justify a strong central government, Elizabeth's ministers bolstered the legitimacy of her regime by continual reference to the weakness, poverty, and false religion of Mary's reign. But no one in their audience needed convincing on these points. The reiteration of this material and the rehearsing of the threats facing the country from abroad form part of the ritual of Parliament, reminding the audience of what unites them and what they have to be grateful for, before moving on to requests or admonitions.

Parliamentary speakers often had recourse to examples, from ancient and foreign history, and from authorities. Archbishop Heath assembled a range of examples from Christian history and quotations from the Apostle's Creed, the Bible, and the church fathers to demonstrate that in passing the Act of Supremacy the church would be forsaking not only Paul IV but also all general councils, all canonical laws, the judgment of all Christian princes, and the unity of Christ's church. ${ }^{64}$ When in 1572 Parliament was attempting to persuade the queen of the necessity of executing Mary, the bishops assembled sixteen pages of arguments supported from Scripture, while the laymen produced fourteen pages of arguments from civil law backed up with historical examples and citations from

63. Ibid., 1:188.

64. Ibid., 1:13-16. 
Roman law. ${ }^{65}$ These arguments had no effect on what everyone knew was a political decision, and indeed the ease with which such batteries of evidence could be assembled (on both sides) exposes the ornamental nature of this type of arguing. It was a fine way to dress up a case and to build confidence among those who supported a particular line but it carried little weight in persuasion.

Closely related to historical arguments are technical ones based on personal knowledge. In his speech for supply in 1576, Mildmay sought to disable the objection that since a payment had been made four years previously, the queen ought not to need more money now. In reply he listed six reasons for the weakness of the queen's finances. These include difficulties in collecting taxes and the expense of repaying debts as well as extraordinary expenditure caused by the northern rebellion, the expedition to Edinburgh, and campaigns in Ireland. Mildmay claimed that these expenses have only been met to date only because of the queen's use of her ordinary revenues. ${ }^{66} \mathrm{He}$ uses his inside knowledge to increase the authority of his arguments, presenting himself as a financial expert favoring his audience with privileged information, for which they ought to show due respect and gratitude:

[A]lbeit her Majestie is not to yield an accompt how she spendeth her treasure, yet for your satisfaccions I will lett you understand such thinges as are very trew, and which I dare affirme, having more knowledg thereof then some other in respect of the place that I hould in her Majestie's service. ${ }^{67}$

His additional information and enhanced authority are then incorporated into an essentially ethical argument. The country ought to reward the queen's financial prudence, in establishing sound coinage and avoiding land sales to cover expenses, with a greater willingness to grant subsidies for extraordinary expenses. ${ }^{68}$ Then he appeals to members' own experience of the rising costs of ordinary expenditure.

Nicholas Bacon was particularly fond of Latin proverbs. ${ }^{69}$ In his closing speeches he three times urged a speedy payment of the subsidy with the tag bis dat qui cito dat [he who gives quickly gives twice]..$^{70}$ However, where Bacon used

65. Ibid., 1:274-90 (with manuscript foliation).

66. Ibid., 1:443.

67. Ibid., 1:443.

68. Ibid., 1:444.

69. Two Latin tags that he uses in the section of his 1571 opening speech dealing with law reform are both repeated from his opening speech of 1563 ; ibid., 1:82-83, 183 .

70. Ibid., 1:48, 189, 466. This proverb is discussed in Erasmus's Adagia, Opera omnia (Leiden, 1703), ii, col. 330. Cato approaches it with "Inopi beneficium bis dat, qui dat celeriter" (Dsr). On Bacon and 
proverbs decoratively, other speakers used rhetorical ornamentation, such as a pithy phrase or an epigram, to express the main argumentative force of their speech. Francis Bacon explained the duty of Parliament with a pseudo-proverb, "We are here to search the wounds of the realme and not to skynne them over." Heneage replied that "the necessitie of the tyme is to be considered," and that "it is strange to counte that impossible which hath beene proved, or that difficulte which hath been used." Robert Cecil based his response on a maxim of practical conduct: "Of twoe mischeifs we must choose the lesser." ${ }^{\text {11 }}$ Perhaps the apparently artless common sense of proverbs made them seem more convincing than pages of evidently worked up authorities. In any case, proverbs and moral maxims were among the staples of grammar school education. The earliest Latin readers were proverbs and ethical sententiae. Pupils were trained to find such maxims in their reading of authors and to employ them in various forms of composition. ${ }^{72}$

Some speakers made use of rhetorical commonplaces to add stylistic gloss and emotional force to parts of their speeches ${ }^{73}$ as we have seen in Bacon's praise of peace and shall see in Hatton's vituperation of Cardinal Allen. Many speeches also employ lively description and dramatization of a scene to elicit an emotional response from the audience. Mildmay attempts to drive home the message of his rather plain speech with the image of wise mariners in time of calm preparing their tackle to withstand a tempest. ${ }^{74}$ Francis Bacon amplified his argument against the payment of three subsidies in six years with the vignette of the farmers selling their cooking pots to pay the tax. ${ }^{75}$ In the peroration to his opening speech in 1589 , Hatton linked together hypothetical syllogism, rhetorical question, and vivid portrayal (with dialogue) of the shipwreck scenario to persuade his audience that they ought to start paying for the next war. He capped his point with comparison, exclamation, proverb, and lively depiction, as well as personification and dialogue:

proverbs, see Elizabeth McCutcheon, Sir Nicholas Bacon's Great House Sententiae, English Literary Renaissance Supplements (Amherst, Mass., 1977).

71. See text at $\mathrm{nn}$. 55 and 56, above. For examples of proverbs used by Francis Knollys and Queen Elizabeth, see text at nn. 87 and 116 , below.

72. John Brinsley, Ludus Literarius, ed. E. T. Campagnac (Liverpool, 1917), 143-44, 175-76, 182-84; M. T. Crane, Framing Authority (Princeton, N.J., 1993), esp. 3-4, 7-9, 44, 49-52.

73. Cicero recommended the preparation of commonplaces, elaborate paragraphs on moral issues that could be inserted into a speech; De inventione, II.15.48-50. The commonplace, like the chreia, an elaboration of the meaning of a sententia, was among the forms of composition described in one of the most popular textbooks of sixteenth-century Europe, Aphthonius's Progymnasmata (London, 1575), sigs. M4v-O6r.

74. Proceedings, 1:442.

75. Ibid., 3:109. 
Our ship is yet safe; and therefore, as one said once in the like case, "Looke mastere, looke mariner, looke everie bodie, that it be not overthrowen by wilfullnes and negligence: for yf the sea get the masterie then it is too late." God forbid that we shoulde ever come to these woords: Lord, whoe woulde have thought we shoulde have come to this? Alas, alas, yf we had done thus and thus all had bene well. ${ }^{76}$

Argumentative techniques and stylistic devices continued to be used as the rhetorical manuals dictated, with such devices supporting or illustrating arguments; but just as frequently in Parliament these functions were reversed, so that stylistic ornament carried the burden of persuasion while argument could be decorative.

\section{STYLE}

In most of the earlier formal parliamentary speeches by members of the Privy Council, the generally sober style of Bacon predominates. In Mildmay's speech for supply, for example, the style is very plain, with only the slightest doubling of adjectives or adverbs to suggest any ambition to impress his audience with his command of elegant expression. ${ }^{77}$ The choice of style may have been dictated by the occasion of these speeches: When the opening of Parliament is concluded, the Commons return to their chamber to elect a Speaker. The speech for supply is followed by other speeches. In neither case is there any immediate action toward which an audience can usefully be driven by the arousal of emotion.

Hatton's speech at the opening of Parliament in 1589 shows that it was possible to speak in a very different way. In presenting the dangers facing the country he attacks the English Catholics, beginning with a list of individuals and their misdeeds (Cardinal Pole, Gardiner, Harding, Morton, Saunders, Campion), which he then abbreviates through occupatio:

I omit here to speake of Morgan, Charles Paget, Throckmorton, and diverse others whoe have bene longe practitioners; but yet of all the villanous traitors that I thinke this lande ever bred or

76. Ibid., 2:424.

77. Ibid., 1:442: "And seeing that by thoes greate occasions which I have remembered you can easelie understand how low her Majestie's cofers are brought, it is our partes here franckly and willingly to offer unto her Majestie such a contribucion as shalbe able to restore the same agayne in such sort as shee may be sufficiently furnished of treasure, to put in order and maynteyne her forces by land and by sea, to answere any thing that shalbe attempted against her and us." 
brought up, that wicked preist, that shamelesse atheiste and bloodie Cardinall Allen, he in deede excelleth. Looke what late daungers have bene anie waie towards us and you shall finde him a cheif dealer in them. He especiallie by his false libells hath sought to bringe this state with all the worlde into perpetuall hatred. He greatlie commendeth Stanlei's treasons and persuadeth others to followe his example. He was the procurer of this last bull, and, it is verie apparaunt, the penner of it. He like a proude and an impudent verlet dareth by his letters to sollicite the nobles and comminalitie of England to ioine with the enemie. He is not ashamed to confesse, and that in writinge that the memorie of his villanie maie never die, howe this Spanish hostilitie hath bene greatlie farthered by his and the reste of these ffugitives indevers. His woords are these. His Majestie (meaninge the King of Spaine) was not a little moved by my humble and continuall suite, together with the afflicted and banished Catholickes of our nation of all and everie degree, to take upon him this holie and glorious acte: that is, the destruccion of this land, the overthrowe of religion, the ruine of hir Majestie and the death of us all. O savage and barbarous preiste! It is much to have suche crueltie attempted by anie foraine enemie: it is more that preists shoulde so delight in bloode. But that English subiects, beinge preists, shoulde take upon them to be the woorkers of such an extremitie, and that against their owne native countrie: before this devilish broode was hatcht, I thinke it was never hearde of amongst the verie Scythians. It is said that the snakes in Siria will not bite nor stinge the people that are borne there; but these most venemous snakes you see doe not onelie labour to bite and stinge us, but, as a generation of cruell vipers, to teare us in peeces and to feede themselves with our bloode. ${ }^{78}$

This is almost a textbook example of amplification, in the form of a sustained vituperation. Hatton prepares for it by passing over several names to concentrate on Allen. Then he builds a series of patterned phrases (anaphora, isocolon), setting out different aspects of Allen's encouragement of treason, making it seem greater by going into detail in the way De copia recommends. ${ }^{79}$ Next he develops Allen's shamelessness- he has left a permanent record of his support for the 
invasion - and his hypocrisy, by pointing out the gap between Allen's emollient words and the barbarous deeds rhey refer to ("this holie and glorious acte: that is, the destruccion of this land"). Hatton works this up by three patterned phrases elaborating its implication ("the overthrowe of religion, the ruine of hir Majestie and the death of us all") before bursting out with his apostrophe ("O savage and barbarous preiste!"). This leads, after a pause no doubt, to a new amplification through an incremental series of comparisons (incrementum): this would be dreadful in a foreign enemy, worse in a priest, but unthinkable until now in an English priest. ${ }^{8 \circ}$ Finally he turns to ancient barbarians and "unnatural natural history" to expand on the unprecedented savagery he attributes to Allen.

It is a highly emotional passage, almost Marlovian in its stylistic intensity and excess. More an episode of vituperation than a deliberative argument, this is far more emotional than anything Bacon attempts. But why? There is no question of the members of Parliament rushing to Rome and dismembering Allen at the end of this speech. Not even any question of an immediate subsidy vote. Rather they will return to the Commons to elect a Speaker, who has already been chosen for them. The motivation for this impressive speech is somewhat similar to Bacon's, however different in form and character. Hatton is rehearsing a set of emotions that the whole House can subscribe to. Rather than inflaming them to action, he aims to unite them. The emotion he arouses is at the service of the ritual, or epideictic, function of identification with the audience. His style may also reflect the mood of the times, when his audience had every reason to feel threatened by the "holy and glorious acts" undertaken by the king of Spain. But we should also notice the position of this emotional episode within Hatton's speech. Once he has described the aggressive intentions of the Catholic powers and established that their main objective is to bring about a change in religion, he turns to the extreme Protestants in Parliament:

And yet herewithall hir Majestie is not so much greived-because she ever accounted them hir enemies and never looked for anie better at their handes-as she is that ther are diverse of latter daies risen up, even amongst hir freinds, whoe beinge men of a verie intemperate humour doe greatlie deprave the present estate and reformacion of religion, so hardlie attained to and with such hir daunger continued and preserved, whereby hir lovinge subiectes are greatlie disquieted, hir enemies are incouraged, religion is slaundered, pietie is hindered, schismes are maintained, and the peace of the Church is altogether rente in sunder and violated. ${ }^{81}$

8o. Ibid., 218.

81. Proceedings, 2:419. 
By emphasizing the difficulty and danger with which the present settlement has been attained, Hatton is able to portray the Puritans as intemperate people who risk what has already been won with difficulty for the sake of getting their own way in minor details. He employs amplification from effects, isocolon, and doubling of epithet to emphasize the dangers caused by their actions.

The paragraph that follows is even firmer, emphasizing the queen's absolute commitment to the present state of the church ("that both in forme and doctrine it is agreable with the scriptures, with the most auncient generall councells, with the practise of the primitive church and with the iudgementes of all the olde and learned fathers") and her rejection of its Protestant critics ("absurde ... intollerable innovacion ... unspeakeable tyrannie ... most daungerous to all good Christian government"). She entreats Parliament-and if that will not suffice, she requires them-not to discuss such matters. It is noticeable that Hatton delivers this section of the speech very definitely in the queen's name before adding his own view that Parliament should carry out her wishes. ${ }^{82}$ Once the instruction has been delivered he returns to the plans of Cardinal Allen and the activities of the seminary priests.

The vituperation against a common enemy thus serves to unite Parliament before his much more contentious criticism of Protestant innovation. It also aids his presentation of the queen as an embattled but firm champion of Protestantism, whose church settlement it would be foolish and ungrateful to attack. The unprecedented - in the context of an opening speech-emotional force of Hatton's oration may be a consequence of the occasion, the first assembly of Parliament after the defeat of the first Armada, when it was widely believed that another threat of invasion would soon arise. Perhaps Hatton's personality was the determining factor. But the more elaborate style that he employs may also reflect a shift in literary taste. Speaker Yelverton's oration at the close of Parliament in 1598 employs an almost euphuistic degree of stylistic elaboration:

If that comon wealth (most sacred and most renowned Quene) was reputed in the world to be the best-framed, and the most likely to flourishe in felicitie, where the subjectes had there freedome of discourse, and there libertie of likeing, in establishing the lawes that should governe them; then must your Majestie's mighty and most famous realme of England (by this your most gratious benignitie) acknowledge it self the most happie of all the nations under heaven. ... Singuler was the commendation of Solon that sett lawes among the Athenians; passing was the praise of Licurgus

82. Ibid., 2:419-20. 
that planted lawes among the Lacedemonians; and highly was Plato extolled that devised lawes for the Magnesians; but neither yet could the inconveniences of the state be so providently foreseene, nor the reason of the lawes be so deepely searched into ... as when the people themselves be agents in the frameing of them. ${ }^{83}$

As well as being much freer in his use of classical allusion and alliteration combined with parison-in Lyly's manner-than earlier speakers, Yelverton also indulges in a series of parallels from natural history and cosmology. ${ }^{84}$ Yet the structure underpinning the decorative elaboration is based on argument from comparison and contrary. Yelverton's amplification usually serves to flatter the queen, but he also uses the favorable atmosphere this creates to make serious points about the impact of court monopolies. ${ }^{85}$ Thus the Parliamentary expectation that serious business required the setting aside of rhetorical elaborateness may have changed.

\section{Opposition, Free Speech, and Honest Counsel}

The practice of debate in the Elizabethan Parliament enabled views opposed to the government line to be registered. Such views, as we have seen, required management and response. Sometimes the impact was more formidable. Members of Parliament could make interventions that annoyed Privy Councillors and that altered the direction of legislation in ways that the council did not foresee. In the debate on the Bill on Vagabonds in 1572, several members suggested amendments and additions to Sir Francis Knollys's bill. Many of these men (Sampole, Lovelace, and Norton, for example) are normally thought of as supporters of the Privy Council line. ${ }^{86}$ These speakers made a series of detailed points that may be divided into three categories: notices of defects in the bill and suggestions for their improvement (for example, Norton's three drafting points, which restrict the definition of vagabond; Seckerston's comment on the lack of provision for the smaller boroughs, including Liverpool, which he represented; and Sampole's comments about bail and division of costs of the carriage of rogues); observations on the causes of poverty (Seckerston's comment on the reluctance of wealthy men to employ servants and St. John's remark on the folly of building of cottages without adequate land to provide food); and suggestions for further mea-

83. Ibid., 3:197-210 at 197.

84. Ibid., 3:198; see G. K. Hunter, John Lyly: The Humanist as Courtier (London, 1962), 264-68.

85. Ibid., 3:203-4.

86. Ibid., 1:366-67. See Elron, Parliament, 101, 352; M. A. R. Graves, Thomas Norton: The Parliament Man (Oxford, 1994), esp. 71-76, 86-88, 187-96, 339-46. 
sures (Lovelace's remarks on the suppression of poverty in Worcestershire and Slege's wish to extend the provisions of the bill to towns and to restrict the minstrels covered by it).

Set against these comments are the attempts by the Lord Treasurer, Sir Francis Knollys, presumably representing the Privy Council view, to push the bill through without extensive revision. He pointed out to the House that this was their own bill, lost in the previous session and now returned to them by the Lords. To attempts to add to the bill he replied with a maxim that it was "better to do some good than by trying to do all good to doe no good. ${ }^{187}$ Knollys was supported by Thomas Seckford, the Master of Requests, ${ }^{88}$ who argued that justices of the peace already had the powers to carry out Lovelace's proposals and that if there were defects in the bill they could be reformed at the end of the seven-year trial period. Although the government supporters of the bill appeared to prevail at this stage, ${ }^{89}$ when it returned to the House it ran into so much opposition that it had to be sent to committee. Some of the objections we have noted re-emerged-for example, the issue of the inclusion of minstrels in the bill, which was much debated later, ${ }^{90}$ and St. John's proposal about land for cottages, which was eventually defeated in this Parliament..$^{1}$

Ordinary members could oppose councillors on apparently equal terms, could deny them the last word, and could, on occasion, have the satisfaction of seeing their views prevail even after the councillors had outgunned them. Francis Alford had such satisfaction in 1572, when he argued against the Privy Council line and against all previous speakers that it would be wrong to execute Mary. ${ }^{92}$ An individual member could offend all shades of opinion in the House and at the same time divide the government speakers on the best way of dealing with him, as Arthur Hall did when he argued on 15 May 1572 that both the duke of Norfolk and Mary should be pardoned, on the grounds that their proposed marriage was essentially a private matter. ${ }^{93}$

\section{Proceedings, 1:367.}

88. This seems most probable, in view of Seckford's involvement with this bill at a later stage (ibid., 1:313, 367); Hartley treats the two Seckfords as different individuals.

89. Since the bill received a second reading on 22 May; ibid., 1:372.

90. Peter Roberts, "Elizabethan Players and Minstrels and the Legislation of 1572 against Retainers and Vagabonds," in Fletcher and Roberts, eds., Religion, Culture, and Society, 34-41; Elton, Parliament, 269-70.

91. Proceedings, 1:311, 372, 384 .

92. Ibid., 1:364-65. The queen refused to act on the advice given her by Parliament, probably for reasons similar to the ones Alford gave. The Statute on Vagabonds, which passed in 1572, as noted above, started as a private initiative rejected by the Lords in 1571. For the earlier Parliaments of the reign, Elton has a list of measures that failed at one Parliament only to succeed at another; Parliament, 120.

93. Ibid., 1:354-59, 366. M. A. R. Graves, "The Management of the Elizabethan House of Commons: The Council's 'Men of Business,'” Parliamentary History 2 (1983): 11-38 at 24-30. 
One member, Peter Wentworth, could say the unthinkable without incurring disqualification or, apparently, much affecting the conduct of parliamentary business. Although he was in due course interrupted and sent to the Tower, he was later pardoned and returned to the House. Here is the climax of his speech at the beginning of the session in 1576 , through the point at which he was interrupted: ${ }^{94}$

And shall I passe over this weighty matter so lightly or soe slightly? May I discharge my conscience and dutye to God, my prince and country soe? Certaine it is, $\mathrm{Mr}$ Speaker, that none is without fault, noe, not our noble Queen. Since then that her Majestie hath committed great faultes, yea dangerous faultes to her selfe and the state, love, even perfit love voyd of dissimulacion, will not suffer me to hide them to her Majestie's perill but to utter them to her Majestie's safetye. And these they are. It is a dangerous thing in a prince unkindly to intreat and abuse his or her nobility and people as her Majestie did the last parliament; and it is a dangerous thing in a prince to oppose or bend her selfe against her nobility and people, yea, against most loving and faithfull nobility and people. And how could any prince more unkindly intreate, abuse and oppose her selfe against her nobility and people then her Majestie did the last parliament? Did shee not call it of purpose to prevent trayterous perills to her person and for noe other cause? Did not her Majestie send unto us two billes, [probably Wentworth was interrupted here] willing to make a choyce of that we liked best for her safety and therof to make a law, promising her Majestie's royall consent therto? And did we not first chuse the one and her Majestie refused it, yielding noe reason, nay, yielding great reasons why she ought to have yielded to it? Yet did not we never the lesse receive the other and agreeing to make a law thereof did not her Majestie in the end refuse all our travells?"5

From the purely stylistic point of view this passage is perhaps excessively repetitive and too reliant on the figure of rhetorical question. But it is nevertheless im-

94. Wentworth was committed to the Tower by a committee of the House on 8 February and was forgiven by the queen and returned to the House on 11 March; Proceedings, 1:477, 491. See also 1:425-34; and Elton, Parliament, 347. Wentworth modeled the opening of his speech on the chreia, beginning with the sentence "Sweet indeed is the name of liberty, and the thing itself a value beyond all estimable treasure," and on the Lord Keeper's opening speeches, reminding his audience of the reasons for calling a Parliament (p. 425). The deliberative argument in favor of free speech (pp. 425-28) soon gives place to a narrative of royal intervention in the previous Parliament (pp. 428-32).

95. Proceedings, 1:430-31. The point of interruption is indicated in Cromwell's journal; ibid., 1:476. 
pressively vehement and passionate as well as being extraordinarily daring in its forthright criticism of the queen's conduct. The narratives in Wentworth's speech make it clear that, although he is nominally concerned with freedom of speech, his real purpose is to resist the queen's manipulation of parliamentary business and to impose Parliament's views on her. There is reason to think that other parliamentarians felt as frustrated as he did at her refusal of both the bills against Mary, ${ }^{96}$ but for the most part they recognized Elizabeth's right to make the final decisions, and they certainly would not have chosen such provocative expressions. In his interrogation by the committee of the House, Wentworth confessed that as he walked on his land, preparing the speech, he half expected that it would take him to the Tower. He decided that his duty to the queen outweighed the risk of imprisonment. When he began to deliver this section of the speech he paused and looked around him:

Yet when I uttered these words in the House, that there was none without fault, noe, not our noble Queen, I pawsed and beheld all your countenances and sawe plainlye that those words did amaze yow all. Then I was afraid with yow for company and feare bad me to put out those wordes that followed, ffor your countenances did assure me that not one of you would stay me of my journey. ${ }^{97}$ Yet the consideracion of a good conscience and of a faithfull subject did make me bould to utter that in such sorte as your honours heard; with this heart and mind I spake it and I prayse God for yt and, if it were to doe, I would with the same minde speake it againe. ${ }^{98}$

Wentworth's comment conveys vividly his sense of the shock and amazement with which the House received his words. As he spoke he knew that he had no prospect of persuading his hearers and that his words would bring him into danger, yet his conscience and his hearers' fascinated astonishment apparently enabled him to utter several more sentences. The speech illustrates the extent of what could be said in Parliament, as well as the consequences of such speech. Though far more passionate than Archbishop Heath's speech against the Bill of Supremacy in 1559 , Wentworth's was equally peripheral to normal parliamentary action: he did not expect to persuade anyone and no one was persuaded. No one

96. In Thomas Cromwell's account of the House's discussion of Elizabeth's rejection of the first of the two bills, on ${ }_{23}$ May 1572, there is a strong sense of the frustration of the members of Parliament. The Speaker sums up by saying, "I have heard none shewe any liking thereof, so as by silence they have all confirmed that which hath beene said by others. It remaineth yow grow to resolucion for the proceeding. Yowe knowe it must finally proceede from the prince"; ibid., 1:373-78.

97. Presumably this phrase means "would prevent my being sent away" (to the Tower).

98. Proceedings, 1:439. 
attempted to prevent his arrest nor, so far as we can tell, spoke publicly in the House in mitigation of his fault. It is possible that the queen was pleasantly surprised by the House's unanimous agreement that his speech had overstepped acceptable bounds. ${ }^{99}$ Certain kinds of opposition created unity more effectively than anything the government could say on its own behalf.

Free speech was a privilege of Parliament-that is, a temporary and institutionally specific suspension of the normal rules of public speech. The existence of limited freedom of speech was itself part of the political contest. ${ }^{100}$ In May 1572, when Elizabeth instructed Parliament not to consider bills on religion that had not been discussed by the bishops, the author of the anonymous journal noted both the affront to the liberties of the House of Commons and the fact that no one spoke to object. ${ }^{101}$ Peter Wentworth and other less radical speakers could emphasize the importance of freedom of expression in order to enlarge the range of what could be discussed. But many of the same people could insist on the limitations on freedom of speech to attempt to silence views that offended them. In the debate on the punishment of Mary, Arthur Hall argued in favor of mercy toward both the queen and the duke of Norfolk. ${ }^{102}$ The following day, Nicholas St. Leger argued that the views Hall had expressed could not be tolerated in Parliament ("Speech ought to be contained in boundes, cankers not to be suffered") and that Hall should be sent to a more secure place. ${ }^{103}$ Edward Fenner replied that while he liked the zeal of the previous speaker he preferred "libertie of speech without restraint." ${ }^{104}$ Long-standing Parliament men such as Alford and Norton saw the need for evenhanded treatment of the issue of liberty and were prepared to speak up for the rights of those whose views they opposed. ${ }^{105}$ Freedom of speech allowed Parliament to define what it was prepared to be persuaded by and what it would unite to oppose (for example, the very different

99. She took the initiative in returning Wentworth to the House; she made no reference to the incident in her warm (though ultimately evasive) speech at the close of session, and she once again prorogued the Parliament rather than dissolving it; Proceedings, 1:471-75, 491, 495.

100. Elton, Parliament, 341-49; David Colclough, "Parrhesia: The Rhetoric of Free Speech in Early Modern England," Rhetorica 17 (1999): 177-212; Stephen Alford, The Early Elizabethan Polity (Cambridge, 1998), 3, 7-8, 151; and John Guy, "The Rhetoric of Counsel in Early Modern England," in Hoak, ed., Tudor Political Culture, 292-310 at 301-4.

101. "The messag that forbad the bringinge of billes of religion into the House semed much to impugne the libertie of the House, but nothinge was saied unto it"; Proceedings, 1:331. It is almost inconceivable that this comment could have been made by someone writing primarily for Burghley, as Elton assumes (Parliament, 11-15).

102. Proceedings, 1:273, 326, 354 .

103. Ibid., 1:355.

104. Ibid.

105. Ibid., 1:360-61. Graves, Thomas Norton, 353-58. 
views of Wentworth and Hall). In that sense, freedom of speech allowed consensus to be defined. Cromwell reports Sir Francis Knollys's words on Hall's speech:

He sheweth that he wisheth speech in the Howse to be free, and that he had rather knowe men by their speech then not to knowe them by their scilence. He would have all blockes removed from the perverse, who otherwise would saie that they were denied speech, that they were able to answere but durst not. Therfore give them scope, let them speake their fill. We are not to be wonne from this course, nor to be abused by their sayinges. ${ }^{106}$

This is a stronger defense of free speech than the government side usually gave, but it emphasizes a gap between what might be said and what might persuade.

\section{The Queen in Parliament}

Much has been written about the way Privy Councillors used Parliament to put pressure on the queen. ${ }^{107}$ The queen could, and did on occasion, respond to such pressure merely by refusing her consent to a bill Parliament passed, ${ }^{108}$ but she preferred not to do this. When the House raised topics that she considered to lie within her own prerogative, or to be more a matter for convocation than for Parliament, she sought to cut short discussion before it could reach a conclusion. ${ }^{109}$ This tactic was not always successful and the House quite frequently discussed matters of religion or succession that she regarded as outside their competence. ${ }^{110}$ On other occasions she herself made carefully crafted speeches to the House or to its representatives. ${ }^{111}$

\section{Proceedings, 1:359.}

107. Graves, "Management," 24-30; Elton, Parliament, 358-77; Hartley, Elizabeth's Parliaments, 165-66.

108. Proceedings, 1:172, 418; Neale, Elizabethan House of Commons, 409-11; Elton, Parliament, 125-26.

109. Proceedings, 1:160-62; Neale, Parliaments, 1:157-58, 221, 273, 419-20; Elton, Parliament, 123.

110. The notion of what Parliament could properly discuss was highly malleable. Tudor monarchs invited Parliament to discuss religion and the succession when it suited their purposes, but Elizabeth wanted such matters discussed only on her terms; Hartley, Elizabeth's Parliaments, 60.

111. David Harris Sacks, on "The Countervailing of Benefits," considers the "golden speech," especially the gestures (p. 289). Among the considerable literature on Elizabeth's orations are Alison Heisch, "Queen Elizabeth I: Parliamentary Rhetoric and the Exercise of Power," Signs 1 (1975): 31-55; Mary Thomas Crane, "Video et Taceo: Elizabeth I and the Rhetoric of Counsel," Studies in English Literature 28 (1988): 1-15; Frances Teague, "Queen Elizabeth in Her Speeches," in S. P. Cerasano and Marion Wynne-Davies, eds., Gloriana's Face: Women, Public and Private in the English Renaissance (Hemel Hempstead, England, 1992), 63-78; S. Frye, "The Myth of Elizabeth at Tilbury," Sixteenth Century Journal 23 (1992): 95-114; and Steven W. May, "Recent Studies in Elizabeth I," English Literary Renaissance 23 (1993): 345-54. For modernized editions and translations, see Elizabeth I: Collected Works, ed. Leah S. Marcus, Janel Mueller, and Mary Beth Rose (Chicago, 2000). 
Queen Elizabeth was notoriously conscious of the effect she created. On 12 November 1586, before a delegation from both Houses of Parliament that was attempting to persuade her to order Mary's execution, Elizabeth spoke openly about her preoccupation with her persona:

[F]or wee princes I tell you are set on stages, in the sight and veiw of al the worlde duly observed. Th'eyes of many behold our actions, a spott is sone spied in our garments, a blemish quickly noted in our doinges. It behoveth us therefore to be carefull that our proceedings be just and honorable. ${ }^{112}$

This awareness of her position in the public gaze and the need to present herself and her actions as entirely blameless emerges also in her account of her response to Mary's alleged crimes:

And now albeit I finde my life hath bin ful daungerouslie sought, and death contrived by suche as no desurt procured it, yet am I thereof so cleare frome malice, which hath the propertie to make menne gladde at the falls and faultes of theire foes and make them seeme to do for other cawses when rancor is the ground, yet I protest it is and hath bin my grevous thoght that one not different in sex, of like estate, and my neare kinne, shold be fallen into so great a crime. Yea I had so litle purpose to pursue her with any coloure of malice, that as it is not unknowne to some of my Lords here (for now I will play the blabb) I secretlie wrote her a lettre upon the discoverie of sondry treasons, that if she wold confesse them and privatlie acknowledge them by her lettres unto my self, shee never should nede be called for them into so publike question. Neither did I it of minde to circumvent her, for then I knew as much as she cold confesse, and so I did write. ${ }^{113}$

Although Mary has sought her death, Elizabeth claims that she bears her no malice but rather is saddened by her crime and anxious to offer her another chance of mercy. Elizabeth is aware that her suggestion is double-edged because it invites Mary to incriminate herself, but she protests her innocence while letting her audience draw the implication that Mary is unrepentant and therefore dangerous. In putting herself in the right and Mary in the wrong in so many different ways, Elizabeth risks giving the impression of excessive artfulness. That she is willing to take this risk shows how concerned she is to give a public dis-

113. Ibid., 2:249. This is Hartley's edition of British Library, MS. Lansdowne 94, with deletions removed. 
play of her mercy, before a group who would have preferred severity. On this occasion she was seeking to impress and conciliate not the immediate audience but, as her use of the stage image implies, the European princes of her time and the judgment of a future generation. The Privy Council may have used Parliament to put pressure on the queen, but the queen could also use Parliament as a platform for addressing other audiences, and for showing them the pressure she was under.

At the closing of Parliament in 1576, Elizabeth interrupted Bacon's speech on her behalf to reply to the Speaker's remarks on the succession. She decided (and the unusual adjournment of the previous day's proceedings had given her time to ponder her speech) to approach the issue obliquely.

Doo I see Gode's most sacred woorde and text of hollie writt drawen to so divers senses bee it never so presiselie taughte, and shall I hope that my speach can pas foorth thorowe so meanie eares withoute mistakinge, wheare so meanie ripe and divers wittes doo ofter bende to conster then attaine the true and perfect understandinge? If anie looke for eloquence, I shall deceave theire hope. If sum thinke I can mach theire guiftes that spake before, theie houlde an open heresie. I can not satisfie theire longinge thristes that wach for thease delightes unles I shoulde affoorde them what my self had never in possession. If I shoulde saie that the sweetest toonge or eloquentest speach that evar was in man weare able to expres that restles care which I have ever bent to governe for your greatest weales, I shoulde most wronge myne entent and greatelie bate the meritt of my owne endevoure. ${ }^{114}$

In her opening sentence Elizabeth carefully doubles her epithets and balances her phrases to give an impression of seriousness and elegance of style, but her subject is the impossibility of being understood. The second sentence is as brief as it is symmetrical. Its successors imitate the openings of each half ("If anie looke / If sum thinke; I shall deceave theire hope / I cannot satisfie theire longinge thristes"), but she uses the formal resources of style to disclaim eloquence. This opening paragraph takes the inexpressibility topos to a new extreme. Anything that she might say is effectively disabled, since her audience is bound to mistake her meaning, since she is incapable of eloquence or even of matching previous

114. Ibid., 1:471. The queen's satisfaction with this speech is confirmed by her note sending a copy of the speech to her godson, John Harington: "Ponder [these words] in thy hours of leisure and play with them till they enter thy understanding. So shalt thou hereafter perchance, find some good fruits hereof when thy godmother is out of remembrance"; Neale, Parliaments, 1:367-68. 
speakers, and since even the greatest eloquence would fall short of describing her care for the commonwealth.

In the second section of the speech she denies any personal merit for her success, attributing all the benefits that the Speaker had listed to God. Her greatest boast is the loyalty of her subjects, which she contrasts with a commonplace description of the inconstancy of all human relationships. The commonplace of ordinary human inconstancy is in turn contrasted with her own constancy, especially in religion:

If pollicie had beene preferred before truth, woulde I, tro you, even at the first beginninge of my rule have turned upsidowne so greate affaires, or entred into tossinge of the greatest waves and billowes of the worlde that might, if I had sought my ease, have harbored and cast ancor in most seeminge securitie? It can not bee denied but worldlie wisdoome rather bad me knitt and mach my self in leage and fast aliance with great princes to purchase ffrendes one everie side by worldlie meanes, and theare repose the trust of my strength wheare force coulde never wantt to geave assistance. Was I too seeke that by mane's outwarde iudgmentt this must needes be thought the safest coorse? No, I can never graunt my self so simple as not to see what all mene's eies discovered. But all thease meanes of leauges, aliances and foreine strengthes I quite forsooke, and gave myself to seeke for truth withoute respect, reposinge my cheefe staie in Gode's most mightie grace. Thus I began, thus I did proceede, and thus I hope to eande. ${ }^{115}$

The logic of her position here is that in defiance of every kind of political expediency, she had from the beginning of her reign committed herself to the truth of the Reformed religion. This strong underlying theme is elaborated through hypotheticals and contraries, as if the position she has taken can only be explained by describing the attractions of the paths she has refused. Even her description of her religious commitment is introduced through a distancing device. While the balances and meanderings of the earlier sentences are effectively answered by the contrasting direct assertions at the end ("Thus I began, thus I did proceede, and thus I hope to ende"), her approach enables her to evade the possibility of setting out her own position clearly and in detail. The vagueness helps her claim credit from her audience for their approval of Protestantism without spelling out the difference between her version of the Reformed religion and theirs. There is also an implied criticism of their attempts to force further reform: how can you

115. Ibid., 1:472 (with minor alterations). 
doubt my commitment to Protestantism when I have stood up for it although every consideration of prudent statesmanship suggested caution?

Then she reminds her audience of the peace and prosperity they have enjoyed under her rule, before (again) deflecting all merit for her success to God and emphasizing her care for the safety of her people. This part of the speech resembles the party line of her councillors' speeches, when they extol the benefits of the queen's reign before asking for additional subsidies. In this manner two-thirds of the speech is given over to preparation before she touches on the topic of marriage (again in words very similar to those used by the Lord Keeper on her behalf). Personally she would prefer not to marry, yet she is willing to set aside her private wishes for the benefit of the state. She knows she is mortal and for that reason she prepares herself for death-this opens the way for more commonplace reflections:

My experience teacheth me to bee no fonder of thease vaine delightes then reason woulde, nether further to delight in thinges uncertaine then maie seeme convenient. But lett good heade bee taken least that reachinge to far after future good you perrill not the presentt, or begine to quarrell or faule together by the eares by dispute before it maie bee well discided who shall weare my crowne. ${ }^{116}$

After all this preparation and self-presentation, the main message of the speech is delivered glancingly, in the form of a proverb: you may endanger the present by taking too much care over the future. She regards the topic of the succession as so divisive that she has no wish to broach it. In conclusion she urges them again not to misunderstand her, promising them that she will provide for their future security and by bestowing her thanks and blessings on them. The speech is a masterpiece of obliqueness, emphasizing her firmness where she knows her audience is on her side, insisting on her willingness ro overcome her own preferences for their advantage, covering the subject at issue, on which she intends to disappoint them, with a surface show of pliancy. She is evidently announcing her wish to present herself favorably and to please her audience, while retaining her freedom of maneuver by evading the commitment they seek. One can also wonder whether her expression is not too elaborate. Although most of her audience would have been charmed by her manner, in the end they may have been uncertain of what position she was actually taking.

The queen did not aim to persuade her immediate audience, nor was there any pressure on her to do so. She apparently wished to charm them, however, so as to lessen any resentment of her deferral of action. Although in strict terms of 
power she had no need of their approval, yet the situation of expressing herself to representatives of Parliament produced a moral pressure to seek their understanding. Whatever the limitations on Parliament's freedom of action, when it was in session it generated situations in which reasons came to be given by the most powerful people in the country to those who were, in the ordinary course of affairs, their inferiors.

\section{ConCLUSION}

In Elizabethan parliamentary oratory the distinction between display and persuasion is very fuzzy. Argumentative structures sometimes act as a form of decoration, serving to clarify the terms of a division or to give emphasis rather than to persuade. Arguments and forms of argumentation may also be used to illustrate the speaker's skill, just as speakers sometimes demonstrated the techniques of amplification without apparently attempting emotional manipulation of their audience. Conversely, rhetorical forms often thought of as mainly decorative, such as moral sentences, proverbs, or fictional narratives, seem to carry the main argumentative force of some speeches. Speakers assembled and presented batteries of arguments from Scripture and the civil law without having any impact on the process of decision making or any hope of persuading the unconverted. At the same time, parliamentary ceremonies, such as the ritual exchange of speeches over the monarch's granting of parliamentary privilege, could be used to convey specific political messages.

Some of these phenomena can be explained by the insights into the different forms and functions of oratory that rhetorical theory provides. The theory of epideictic rhetoric enables us to appreciate that many parliamentary speeches function in a way that is almost ritualistic, reaffirming the unity and identity, the shared history and interests, of the moderate Protestant elite. The collection and dissemination of arguments, the repetition of versions of recent history to which all subscribe, even Hatton's arousal of violent emotions against the safely absent Cardinal Allen-speeches that look very different on the surface could share the underlying purpose of uniting the political community in preparation for more contentious requests or admonitions.

Parliamentarians were members of an elite whose culture was formed by oratory and debate. ${ }^{117}$ The form of debate and the shared experience of disputation,

117. Both Nicholas Bacon's disparagement in 1559 of "contentious reasoninges and disputacions" as more suitable to the schools than to Parliament (quoted in n. 24, above) and his urging in 1571 that Parliament speak logice rather than rhetorice (quoted in the text at n. 8, above) assume and draw on the House's shared experience of rhetoric and disputation. 
together with the possibility that disagreement would be resolved by majority vote, produced some obligation on government speakers to answer arguments, to give reasons, and to respond to messages. The queen's councillors in the House of Commons, who did not have the right of veto or the resource of an effectively whipped party, evidently found it an ordeal to be called even to this weak form of account.

Parliamentary speeches altered legislation and provided the basis for action, but they had other purposes as well. Speaking in Parliament served the establishment of individual positions, the satisfaction of local needs, and notably the creation and celebration of political community. Vituperation and immoderate opposition, as much as royal progresses, country houses, and sessions in London, helped establish community between the Privy Councillors and the geographically scattered landed gentry.

In theory Parliament embodied a form of exchange: the queen expected to obtain financial support and to pass her legislative program, while the Lords and Commons expected to air their grievances and to pass local laws useful to their supporters. Evidently there was a degree of fiction about this. The queen was always in practice assured of the vote for supply, while she could always reject any other legislation. But these were final powers that she preferred not to use. Even within Parliament the Privy Council could organize pressure on an individual member or secure a rerun of a vote that it had lost. But this may have been balanced by other forms of fiction. The writ of central government did not run uniformly and effectively throughout the realm. Many interests and shades of opinion were unrepresented in Parliament. Members could vote taxes that in practice they would neither collect nor pay. ${ }^{118}$ The very existence of Parliament seems to have constrained the queen and her ministers into making financial and religious concessions. Parliament was a place where things could be said, where messages could be sent in both directions. Among the many factors determining the extent to which justices of the peace and returning members were able or willing to carry out at the local level the demands of the queen and her ministers were the extent to which they felt incorporated in a political community and the way in which the government responded to the arguments and concerns expressed in the privileged space and time of Parliament.

\section{University of Warwick}

118. The council's anxiety about the commitment of local office holders to parliamentary decisions may be reflected in the exhortation to members, in the Lord Keeper's professedly ceremonial speech at the closing of Parliament, to enforce the laws they have made; for example, Proceedings, 1:9-51, 111-12, 171, 190-91, 417, 464-65, 495; 3:492. 